\title{
Artificial Neural Network and Image Processing Based Compressive Strength Prediction
}

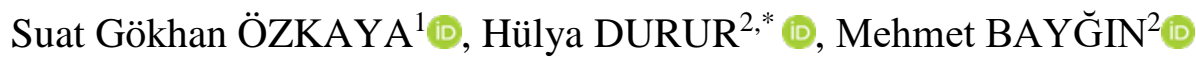 \\ İlker KAZAZ ${ }^{3}$ \\ ${ }^{1}$ Department of Civil Engineering, Ardahan Technical Sciences Vocational School, Ardahan University, \\ Ardahan, TURKEY. \\ ${ }^{2 *}$ Department of Computer Engineering, Faculty of Engineering, Ardahan University, Ardahan, TURKEY. \\ ${ }^{3}$ Civil Engineering Department, Faculty of Engineering and Architecture, Erzurum Technical University, \\ Erzurum, TURKEY.
}

Geliş / Received: 10/03/2021, Kabul / Accepted: 15/07/2021

\begin{abstract}
There are many artifacts from various civilizations in our country, reaching day by day. Historical masonry structures are also among the structures that are considered cultural heritage. For this reason, detailed examination of these historical masonry structures, testing of the samples of this structure and documentation of this information obtained from these tests is a very important issue in terms of ensuring that these structures can be transmitted to future generations in a robust manner.

In this article, it is planned to examine the stones used in masonry structures with computerized vision technology. For this reason, stones with different qualities to be taken from quarries will be taken images primarily through a camera. Later on, the image of each sample will be transferred to the computer environment and the features belonging to these samples will be removed through image processing. Later on, these samples will be tested in the laboratory and their strengths will be measured. Consequently, the data attained from the laboratory environment and the results attained by image processing will be compared and the calibration of this proposed image processing based analysis method will be done. The proposed method was determined as 99.47\%, 93.89\% and 94.19\% for travertine, andesite and limestone, respectively. As a result of these studies, it will be possible to carry out experimental applications in the laboratory environment in computer environment. Again due to these studies very complex and lengthy studies can be significantly shortened; some characteristics of samples taken with a simple camera can be measured very quickly in a computer setting.
\end{abstract}

Keywords: Masonry Structures, Compressive Strength, Image Processing.

\section{Öz}

Yapay Sinir Ağı ve Görüntü İşleme tabanlı Basınç Dayanımı Tahmini

Ülkemizde çok çeşitli medeniyetlerden günümüze ulaşmış birçok eser mevcuttur. Tarihi yığma yapılar da, kültürel miras olarak kabul edilen bu yapıların arasında yer almaktadır. Bu nedenle bu tarihi yığma yapıların detaylı bir şekilde incelenmesi, bu yapılara ait numunelerin test edilmesi ve bu testlerden elde edilen bu bilgilerin dökümante edilmesi, bu yapıların gelecek nesillere sağlam bir şekilde aktarılabilmesi açısından oldukça önemli bir konudur.

Gerçekleştirilen bu çalışmada, yığma yapılarda kullanılan taşların bilgisayarlı görme teknolojisi ile incelenmesi yapılmıştır. Bu amaçla taş ocaklarından alınan farklı niteliklere sahip taşların öncelikli olarak bir kamera aracılığıyla görüntüleri alınmıştır. Daha sonrasında her bir numunenin görüntüsü bilgisayar ortamına aktarılmış ve bu numunelere ait özellikler görüntü işleme yoluyla elde edilmiştir. Daha sonrasında bu numuneler 
laboratuvar ortamında test edilmiş ve dayanımları ölçülmüştür. Sonuç olarak laboratuvar ortamından elde edilen veriler ve görüntü işleme ile elde edilen sonuçlar karşılaştırılmış, önerilen bu görüntü işleme tabanlı analiz yöntemi kalibre edilmiştir. Önerilen yöntem traverten, andezit ve kireç taşı için sırasıyla \%99.47, \%93.89 ve \%94.19 olarak belirlenmiştir. Yapılan bu çalışmalar neticesinde laboratuvar ortamında yapılan deneysel uygulamaların bilgisayar ortamında gerçekleştirilebilmesine olanak sağlanmıştır. Yine bu çalışmalar neticesinde oldukça zorlu ve uzun süren çalışmalar önemli bir ölçüde kısaltılmış, temel bir kamera aracılığıyla görüntüsü alınan numunelerin belirli özellikleri bilgisayar ortamında çok hızlı bir şekilde hesaplanabilmiştir.

Anahtar Kelimeler: Yığma Yapılar, Basınç Dayanımı, Görüntü İşleme.

\section{Introduction}

Basic mechanical properties such as compressive and tensile strength in buildings are very important criteria in determining the properties of the existing structure (Ozkaya et al., 2017). Thanks to these parameters, which allow the behavior of buildings to be examined in the process of real and possible scenarios, the mechanical properties are determined and accordingly, the reactions of the buildings in case of a possible load can be determined. While determining these behaviors of structures, laboratory studies are generally used and these parameters are obtained as a result of laboratory tests.

There are many different measurement methods in the literature. It was seen that methods such as ultrasonic test device, schmitt hammer and uniaxial compressive strength method were used to measure the compressive strength of stones used in masonry structures (Öziçer and Uyanık, 2015; ASTM, 1990; Hornby, 1998; Qixian and Bungey, 1996).

Today, in parallel with the development of computer technology, non-contact and automatic measurement approaches have also been developed. Especially image processing and artificial intelligence-based methods are used to measure the compressive strength in buildings (Chen et al, 2002; Hsiao et al., 2010). Especially problems that take a lot of time to solve and require intensive experimental studies can be easily calculated with computer vision technology and solutions are produced in a short time (Duan et al., 2008; Yazdi et al, 2011).

In one of the studies on the subject, a total of 144 samples were collected. In this study, an automatic concrete compressive strength approach has been developed using image processing and artificial neural network techniques. In the developed application, images of the collected samples were taken by a camera and the features of these images were extracted by image processing. Then, compressive strength values were obtained by using artificial neural networks from the obtained properties. It has been determined that there is a high correlation between the results obtained from the proposed method and the results obtained from real tests (Dogan et al., 2017). In another study on the same subject, a method was proposed using image processing, statistical property extraction and artificial neural network methods. The results obtained in this study show that automatic and non-contact compressive strength can be achieved with the proposed method (Dogan et al., 2015). In another study, a neural network-based method was proposed by creating a total of 100 samples. These samples are divided into training and test sets in a ratio of 85:15. The results obtained from the proposed method showed that the neural 
network-based approach can be used in compressive strength (Ni and Wang, 2000). In another study on compressive strength, multiple regression analysis and artificial neural networks were used. When the estimation results obtained from these methods were examined, it was observed that the highest efficiency was obtained with artificial neural networks (Kewalramani and Gupta, 2006).

Because of these long and laborious studies, the measurement of many buildings is either neglected or examined in a limited way. When the studies in the literature are examined, it is observed that image processing and artificial neural network-based methods are generally used for compressive strength. In this paper, image processing and artificial neural network based analysis of stones used as basic materials in masonry structures was carried out. For this purpose, the proposed method is presented in the second section of the study. In the third section, materials and methods are given. In the fourth section of the study, results and discussion are given. In the fifth and last section, the results are shared.

\section{Proposed Method}

The main purpose of this study is to examine the stones which is used in masonry structures by using image processing based computer vision and to extract some basic mechanical properties of these stones. A block diagram summarizing this implementation is as given in Figure 1.

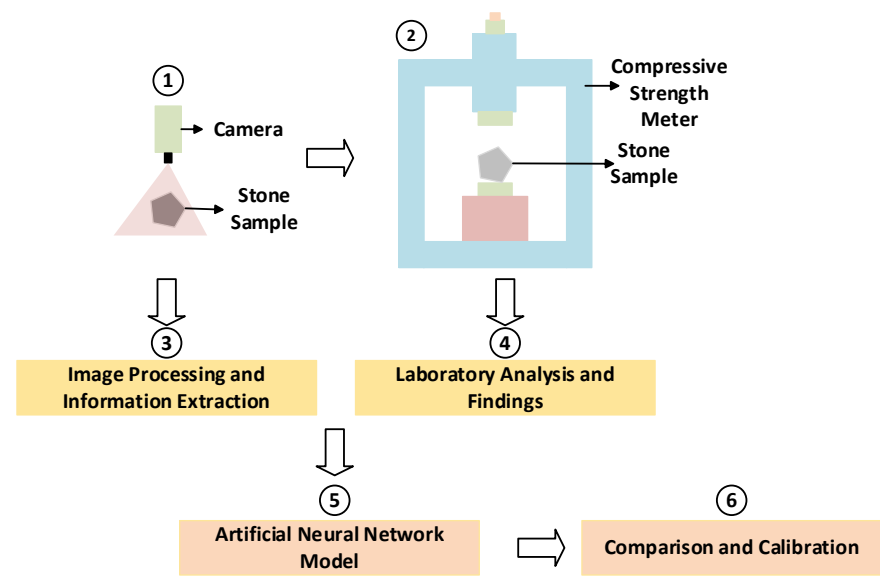

Figure 1. A block diagram summarizing the proposed approach

As can be seen from Figure 1, the first stage of the system is to take images of the stone samples that will be used for the study and will be subjected to tests. Before starting the laboratory analysis of these stones, detailed images are taken. In addition, special attention was paid to obtaining these images at high resolution, allowing each edge on the stone to be seen. In the second phase of this study, laboratory experiments are carried out. In laboratory tests, it was ensured that the real compressive strengths were obtained by crushing the stones. The main reason for this process is to attain the compressive strength of the stones and use it as a calibration value in the application to be carried out later. The compressive strength values obtained as a result of the experiments performed for the samples using the measuring device in the laboratory were transferred to the computer environment for later use. 
The next stage of the system is image processing and feature extraction. Images of stone samples to be used in the study were taken and certain features of these images were tried to be extracted. Basically, the feature extraction process is a set of features that helps to distinguish stones from each other and allows calculating compressive strength. The main purpose of this process is to generate input parameters to the artificial neural networks that will be implemented by the system. In this context, feature extraction process was applied to the images of all samples. These values obtained later were documented and archived for use. In the next stage of the study, the characteristics of the extracted stone samples were adapted to artificial neural networks. For this purpose, the self-qualities obtained in the previous stage were divided into two groups as training and test set. Basically, while the training group covers $75 \%$ of all samples, the remaining $25 \%$ is separated as a test group. The main purpose at this stage is to design the training cluster and artificial neural network and make it fit for purpose. It is aimed to determine some mechanical properties of samples with artificial neural networks, which is a learning approach. Again, the test group to be used in the artificial neural network is used to determine the accuracy of the trained neural network model. This model, which has been trained by using $75 \%$ of all samples, is tested with the remaining $25 \%$ and the accuracy of the model is tested.

The last stage of this work is the calibration process. Basically, the process of matching the attributions obtained at this stage, which is carried out before and within artificial neural networks, with the results obtained in previous laboratory experiments is performed. In this way, it is determined which attribute corresponds to how much compressive strength and the calibration and normalization of the system are provided.

\section{Materials and Methods}

In this paper, the main purpose is to ensure that the compressive strength of stones used in masonry structures is determined entirely by image processing and artificial neural network methods without the need for any contact measurement.

With this study, the compressive strength of stones used in masonry structures was measured. In this context, 3 different types of stones were supplied, respectively travertine, andesite and limestone, and the compressive strengths of these stones were calculated in the laboratory environment. As a result of the studies carried out, image processing and artificial neural network application were developed, and with this application, it was ensured that the compressive strength of the stones was measured without contact. Basically, the attributes of the stones are extracted and given as the input parameter to the artificial neural network designed within the scope of the application, the compressive strength parameter was obtained as the output. A flow chart summarizing the application of compressive strength in non-contact image processing based masonry structures developed within this framework is as given in Figure 2. 


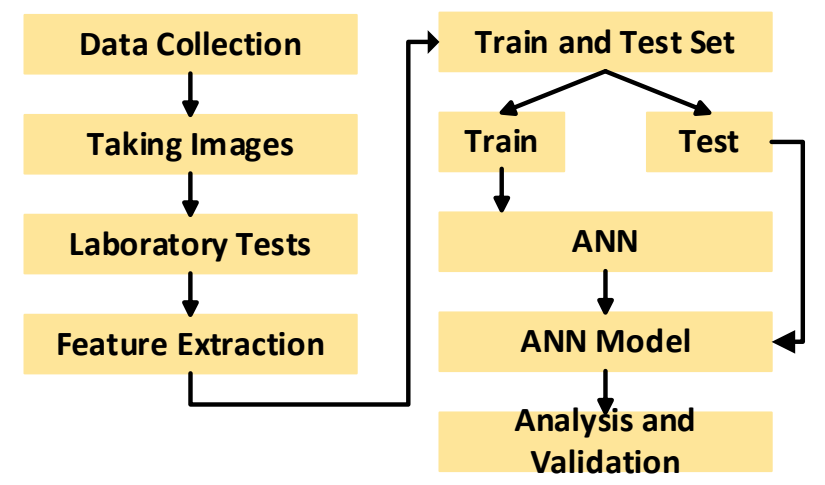

Figure 2. Flow chart of the proposed method

As can be seen in Figure 2, the first stage of the system is sample supply. The images of the travertine, andesite and limestone samples in the study were taken by a camera and transferred to the computer environment for later use. The second stage of the study is to obtain the compressive strengths of these samples by real laboratory tests. These obtained values are also documented and archived for use in the later stages. In the third stage of the study, feature extraction processes were applied to the images obtained. The attributes obtained after this stage were divided into two groups as training and test groups. After this stage, an artificial neural network was designed within the scope of the study. Using the training group, this artificial neural network was able to learn. In the last stage of the system, the test group was tested with this trained model and the results were examined. All these stages realized in the study are presented as subsections in the following sections.

\subsection{Data Collection}

As stated at the beginning of the chapter, three different stone types were used in this study. These are travertine, andesite and limestone, respectively. Sample images of these samples are as shown in Figures 3, 4 and 5, respectively.

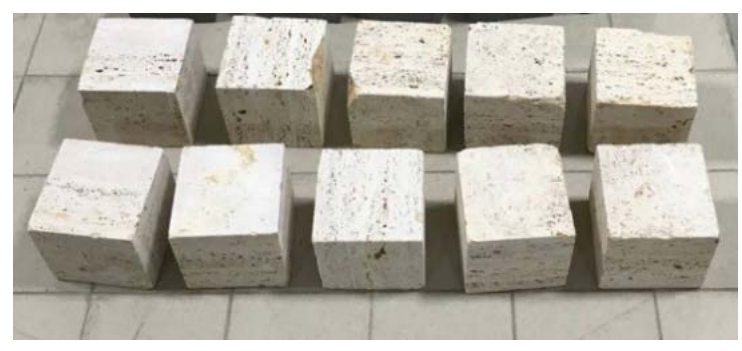

Figure 3. Travertine stone

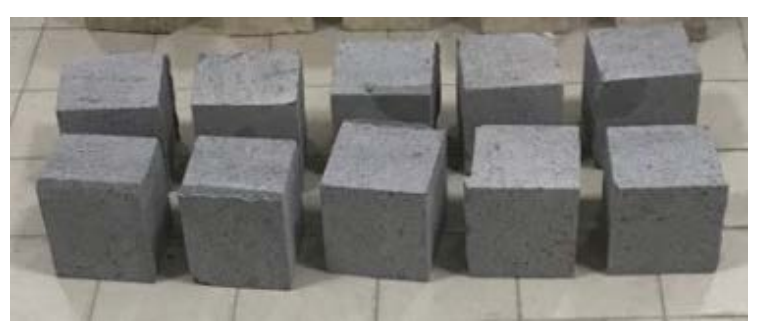

Figure 4. Andesite stone 


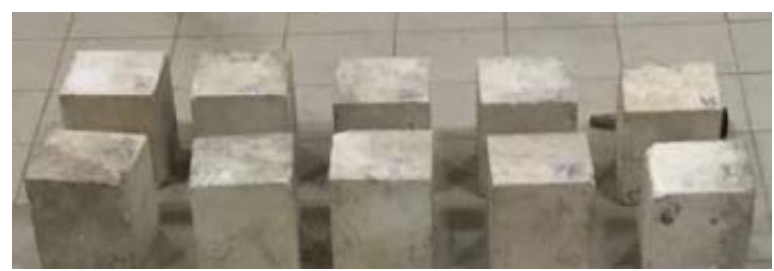

Figure 5. Limestone

As can be seen from the figures, three different types of stone samples were used in the study. A total of 210 sample samples, 70 of each species, were used in the study.

\subsection{Taking Sample Images}

The next stage of his study is taking images of the samples provided. These images taken from the stone samples via a camera are transferred to the computer environment and used in the feature extraction phase. Some sample images obtained within the scope of the study are as given in Figure 6.

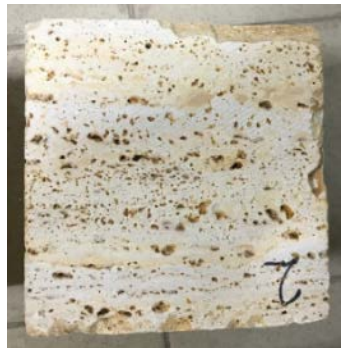

(a) Travertine stone

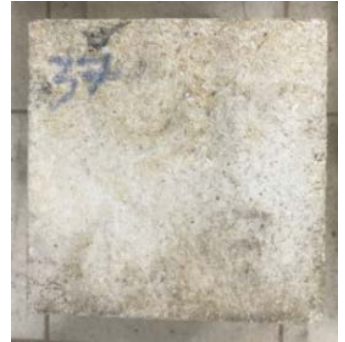

(b) Limestone

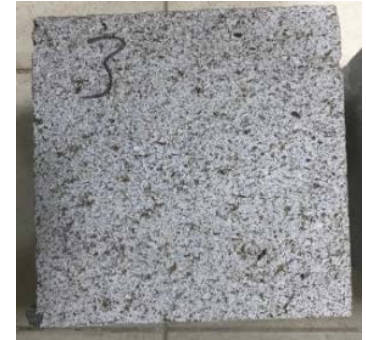

(c) Andesite stone

Figure 6. Taking sample images

As can be seen in Figure 6, each stone sample is numbered separately. The reason for this process is that the laboratory tests to be carried out in the next stage are carried out in a healthy and successful way. Documentation and archiving process is carried out according to the numbers of these stones in the crushing operations to be carried out in the next stage. In Figure 6, only a certain part of the samples taken in the image is given, in the study, a total of 210 samples were obtained and the images of each sample were recorded separately.

\subsection{Laboratory Tests of Samples}

Before proceeding to feature extraction from the images of the samples provided within the scope of the study, the samples were subjected to laboratory tests. During these tests, the samples were subjected to uniaxial compressive strength test and the compressive strength 
values in the laboratory environment were obtained in MPa by crushing the samples. For this purpose, a sample image taken at the time of breaking is presented in Figure 7.

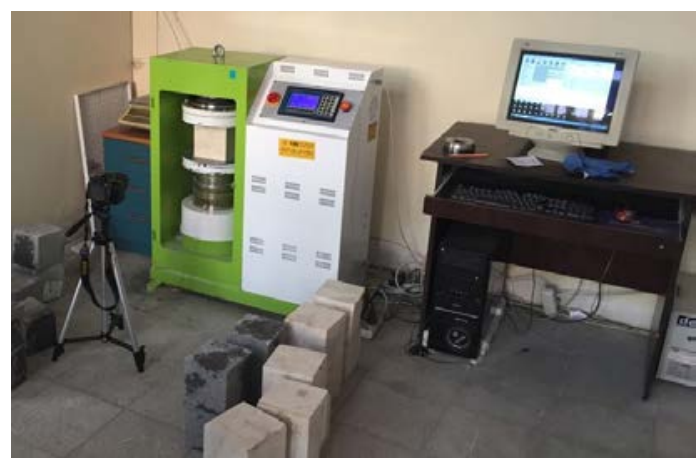

Figure 7. A sample image from the laboratory environment

As can be seen in Figure 7, stones are subjected to a compressive strength test. Stones subjected to pressure are broken after a certain point and the values obtained when they are broken are transmitted to the main machine computer. The changes that some samples have undergone after the crushing process in the laboratory are as shown in Figure 8.
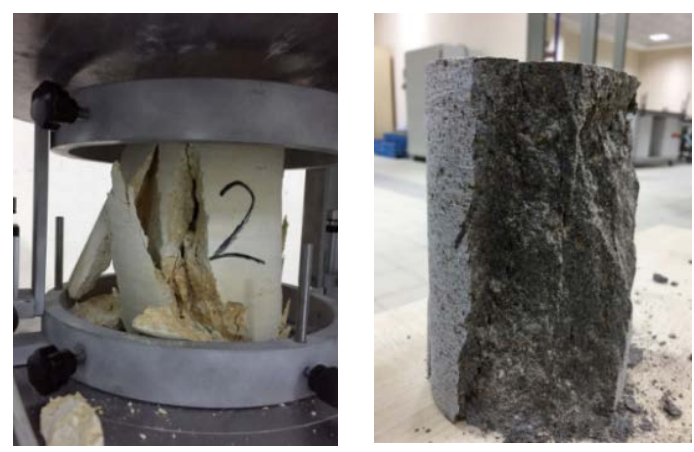

Figure 8. A sample crushing process

\subsection{Feature extraction from images}

At this stage of the study, the necessary information is extracted from the sample images obtained in the previous section. For this purpose, an image processing application was developed and a set of attributes was obtained for each of the samples. A flow diagram summarizing this application developed is as given in Figure 9. In addition, sample images of these steps performed in the study are presented in Figure 10.

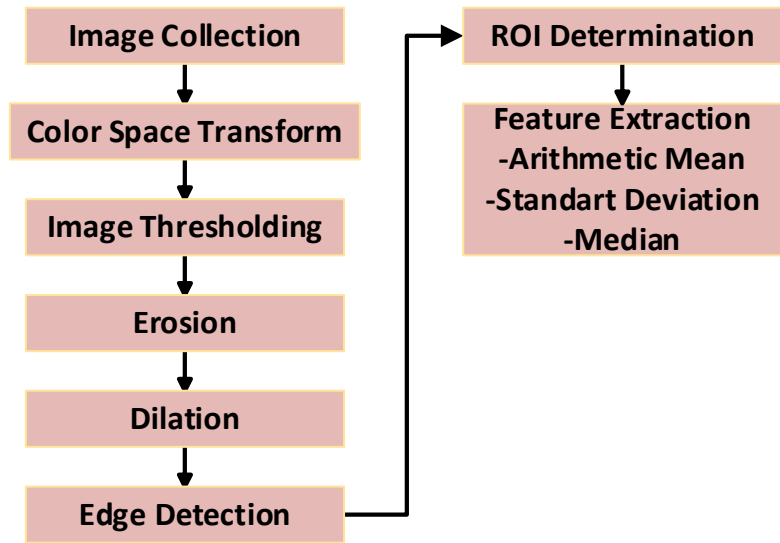

Figure 9. Image processing steps 


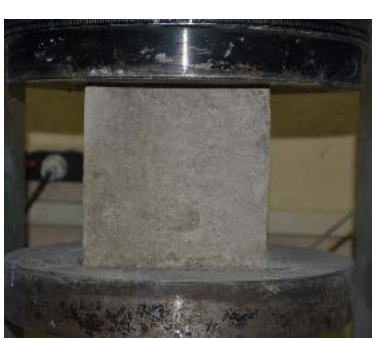

(a) Original Image

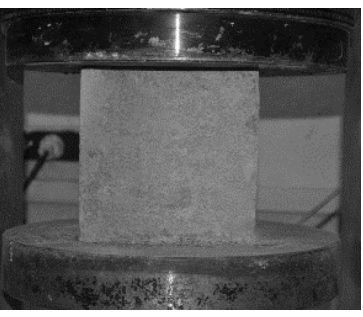

(c) HSV (3. Channel)

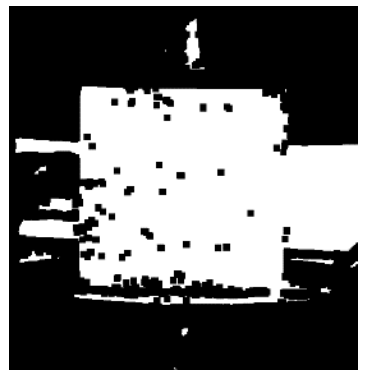

(e) Erosion

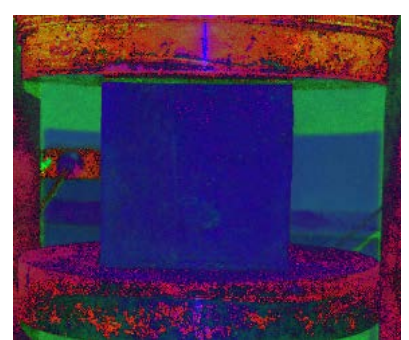

(b) HSV Color Space

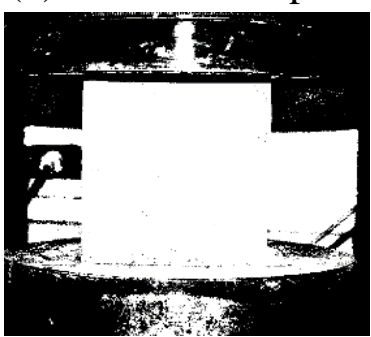

(d) Thresholding

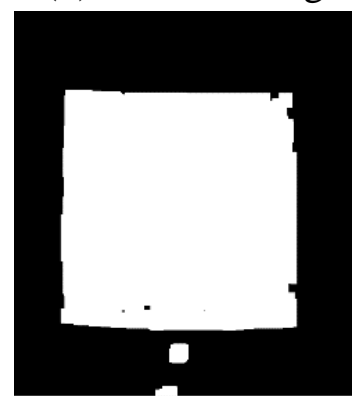

(f) Dilation

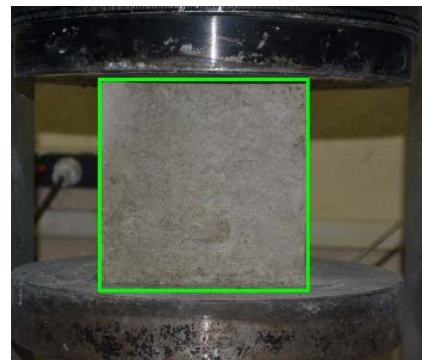

(g) Edge Detection and Roi Detection

Figure 10. Results of image processing algorithm steps with sample

\subsection{Training and Testing with Artificial Neural Networks}

The last stage of the approach proposed in the study is to train the system using artificial neural networks and to test the model obtained as a result of the training with the test group. With this final stage designed, a compressive strength system has been obtained in image processing based masonry structures. A block diagram summarizing this stage realized is as given in Figure 11. 


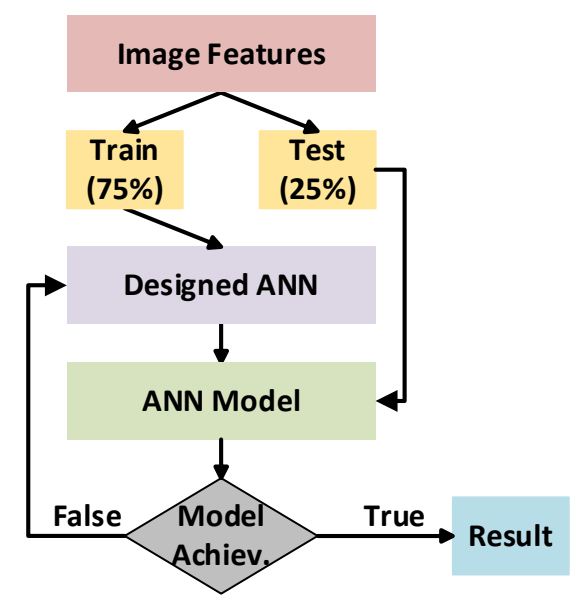

Figure 11. Artificial neural network model of the proposed System

\section{Results and Discussion}

As mentioned at the beginning of the chapter, the main purpose of this study is to measure the compressive strength parameter, which should normally be carried out in the laboratory environment and has a very important place in buildings, using image processing and artificial neural network methods. For this purpose, image processing and artificial neural network methods have been developed and a system model has been obtained. This system model obtained has been subjected to various test processes and the accuracy of the proposed method has been ensured. A schematic block diagram summarizing this work is presented in Figure 12. In addition, sample design parameters of the artificial neural network designed within the scope of the system are given in Table 1.

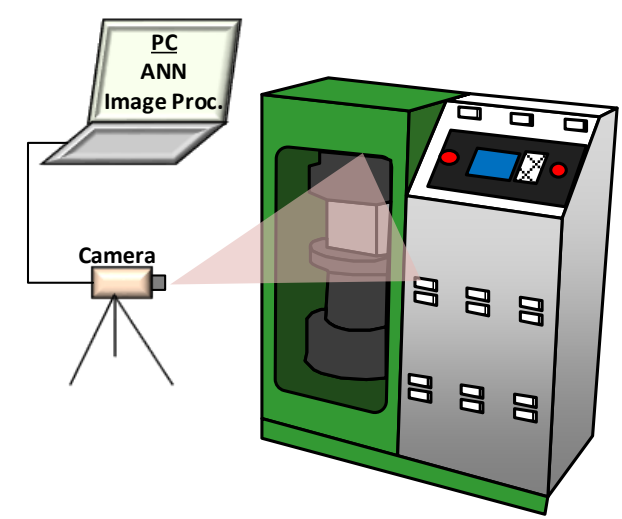

Figure 12. Schematic diagram of the proposed method.

Table 1. ANN design parameters

\begin{tabular}{|c|c|}
\hline Parameters & Values \\
\hline Type & Feed Forward \\
\hline Input Layer & 3 \\
\hline Output Layer & 20 \\
\hline Latent Layer & $1 x e^{-5}$ \\
\hline Learning Rate & $1 x e^{-8}$ \\
\hline Goal & 1000 \\
\hline Iteration & 52 Andesite, 52 Limestone \\
\hline Training Set & 52 Travertine, 52 18 Andesite, 18 Limestone \\
\hline Test Set & 18 Travertine,
\end{tabular}


As can be seen from Table 1, 75\% of the samples were used for the training process, while the remaining $25 \%$ was used for testing and verification of the model realized. Standard deviation, median and arithmetic mean values are obtained for each stone sample as a result of applying attribute extraction processes to the sample images obtained within the scope of the study. These values are given as the input parameter to the artificial neural network. As a result of this process, the compressive strength value of each sample is obtained in MPa. As stated in other sections, the exercises were carried out in two stages. While the first of these stages is the laboratory tests, the second is the application developed. In the training process of the artificial neural network, standard deviation, arithmetic mean and median values obtained from the images were used as input parameters, while the compressive strength parameter obtained in the laboratory environment was used as the output parameter. An example situation showing the values obtained in this framework is presented in Table 2.

As can be seen in Table 2, 3 different examples are presented for 3 stone types. These examples are 52 in total for the input parameter, only a certain part is given in this section. These values were obtained in the feature extraction phase from the image and are used in the training phase of the artificial neural network. From the application obtained in this study, the compressive strength value of the stones is obtained. Later, these values are compared with real laboratory values and the performance of the system is measured. Some sample results obtained as a result of experimental studies are as given in Table 3.

Table 2. Sample training data

\begin{tabular}{|c|c|c|c|c|c|c|c|c|c|c|}
\hline & \multirow{3}{*}{ Parameters } & \multicolumn{9}{|c|}{ Samples } \\
\hline & & \multicolumn{3}{|c|}{ Travertine } & \multicolumn{3}{|c|}{ Andesite } & \multicolumn{3}{|c|}{ Limestone } \\
\hline & & N1 & N2 & N3 & N1 & N2 & N3 & N1 & N2 & N3 \\
\hline \multirow{3}{*}{ 㤩 } & $\begin{array}{l}\text { Standard } \\
\text { deviation }\end{array}$ & 0.0089 & 0.0101 & 0.0093 & 0.0127 & 0.0200 & 0.0136 & 0.0132 & 0.0096 & 0.0080 \\
\hline & Arithmetic mean & 0.4796 & 0.4723 & 0.4724 & 0.3955 & 0.3822 & 0.4730 & 0.5718 & 0.5350 & 0.5219 \\
\hline & Median & 0.4980 & 0.5059 & 0.4784 & 0.4157 & 0.4000 & 0.4863 & 0.6039 & 0.5725 & 0.5569 \\
\hline Oِ & $\begin{array}{c}\text { Compressive } \\
\text { Strength }\end{array}$ & 40.44 & 41.38 & 31.60 & 65.587 & 67.649 & 63.840 & 17.636 & 23.093 & 12.924 \\
\hline
\end{tabular}


Table 3. Experimental results obtained

\begin{tabular}{|c|c|c|c|c|c|c|c|c|c|}
\hline \multirow{3}{*}{ Sample } & \multicolumn{9}{|c|}{ Test Results (MPa) } \\
\hline & \multicolumn{3}{|c|}{ Travertine } & \multicolumn{3}{|c|}{ Andesite } & \multicolumn{3}{|c|}{ Lime Stone } \\
\hline & $(L T)$ & $(P V)$ & $\%$ & $(L T)$ & $(P V)$ & $\%$ & $(L T)$ & $(P V)$ & $\%$ \\
\hline$N 1$ & 30.6961 & 30.3994 & 0.96 & 70.1567 & 69.2916 & 1.23 & 23.8487 & 20.1854 & 15.36 \\
\hline N2 & 35.8407 & 25.3190 & 29.3 & 64.6818 & 71.0181 & 9.79 & 24.4422 & 18.6253 & 23.79 \\
\hline N3 & 27.0017 & 31.4277 & 16.3 & 67.4078 & 71.6336 & 6.26 & 25.1617 & 14.0635 & 44.1 \\
\hline N4 & 33.6008 & 26.6815 & 20.5 & 67.0102 & 67.9249 & 1.36 & 14.1821 & 16.3588 & 15.3 \\
\hline N5 & 33.5522 & 32.1571 & 4.15 & 68.8168 & 64.2476 & 6.63 & 18.5969 & 14.7264 & 20.8 \\
\hline N6 & 28.3262 & 32.6490 & 15.2 & 69.3842 & 64.3436 & 7.26 & 16.6381 & 15.5747 & 6.39 \\
\hline N7 & 30.9495 & 33.4741 & 8.15 & 69.7921 & 65.3175 & 6.41 & 24.2009 & 16.3593 & 32.4 \\
\hline N8 & 24.0619 & 29.3075 & 21.8 & 65.4842 & 70.5664 & 7.76 & 19.0397 & 18.8417 & 1.03 \\
\hline N9 & 23.7553 & 24.1734 & 1.76 & 69.1173 & 65.2885 & 5.53 & 25.7490 & 13.6951 & 46.8 \\
\hline$N 10$ & 30.4311 & 26.2056 & 13.8 & 68.8958 & 70.3285 & 2.07 & 15.5458 & 25.6380 & 64.9 \\
\hline N11 & 33.9083 & 35.7867 & 5.53 & 64.4635 & 65.1917 & 1.12 & 16.6932 & 26.2270 & 57.1 \\
\hline N12 & 36.0761 & 25.1332 & 30.3 & 64.0709 & 71.3633 & 11.38 & 15.0375 & 19.8720 & 32.1 \\
\hline$N 13$ & 24.8186 & 34.5614 & 39.2 & 67.4852 & 66.1498 & 1.97 & 14.9049 & 19.8495 & 33.1 \\
\hline N14 & 30.9635 & 30.5367 & 1.37 & 71.6376 & 64.7693 & 9.58 & 25.1700 & 17.7280 & 29.5 \\
\hline N15 & 29.5714 & 36.9458 & 24.9 & 66.0634 & 65.2597 & 1.21 & 21.1158 & 25.6007 & 21.2 \\
\hline$N 16$ & 23.1666 & 24.0944 & 4.0 & 68.2674 & 68.5444 & 0.40 & 20.6980 & 18.1694 & 12.2 \\
\hline N17 & 27.7197 & 29.1974 & 5.3 & 65.0143 & 67.2595 & 3.45 & 15.0293 & 14.5568 & 3.14 \\
\hline$N 18$ & 25.2705 & 24.4931 & 3.0 & 69.7614 & 66.1649 & 5.15 & 24.9424 & 23.9235 & 4.08 \\
\hline Mean & 29.4283 & 29.5857 & 0.53 & 67.6394 & 63.5020 & 6.11 & 20.0553 & 18.8886 & 5.81 \\
\hline
\end{tabular}

*LT=Laboratory Testing, PV=Prediction Value, \%=Difference Percentage

As can be seen from Table 3, 18 samples were used for each species in experimental studies. The laboratory tests of these samples and the results obtained from the developed model were compared and presented in detail in Table 4.

The results obtained in the laboratory environment and the results obtained from the developed application were primarily proportioned to each other. The most important criterion in evaluating the performance of the developed model is that these values come out as close to each other as possible. In this context, when Table 4 is examined, it will be seen that the results obtained from the laboratory tests and the developed application are very close to each other. In addition, if the general average is examined, it will be seen that the values obtained are very close to the "1" value.

The image processing and artificial neural network based automatic compressive strength detection approach proposed in this study has exhibit very successful results. There are also studies on this subject in the literature. A detailed comparison of the findings obtained in this study with the studies in the literature is given in Table 5. 
Table 4. Comparative results

\begin{tabular}{|c|c|c|c|}
\hline \multirow{3}{*}{ Samples } & \multicolumn{3}{|c|}{ Test Results (Proportional) } \\
\hline & Travertine & Andesite & Limestone \\
\hline & $L T / T D$ & $L T / T D$ & $L T / T D$ \\
\hline N1 & 1.0097 & 1.0124 & 1.1814 \\
\hline N2 & 1.4155 & 0.9107 & 1.3123 \\
\hline N3 & 0.8591 & 0.9410 & 1.7891 \\
\hline N4 & 1.2593 & 0.9865 & 0.8669 \\
\hline N5 & 1.0433 & 1.0711 & 1.2628 \\
\hline N6 & 0.8675 & 1.0783 & 1.0682 \\
\hline N7 & 0.9245 & 1.0685 & 1.4793 \\
\hline N8 & 0.8210 & 0.9279 & 1.0105 \\
\hline N9 & 0.9827 & 1.0586 & 1.8801 \\
\hline$N 10$ & 1.1612 & 0.9796 & 0.6063 \\
\hline$N 11$ & 0.9475 & 0.9888 & 0.6364 \\
\hline N12 & 1.4353 & 0.8978 & 0.7567 \\
\hline$N 13$ & 0.7181 & 1.0201 & 0.7508 \\
\hline N14 & 1.0139 & 1.1060 & 1.4197 \\
\hline$N 15$ & 0.8003 & 1.0123 & 0.8248 \\
\hline$N 16$ & 0.9614 & 0.9959 & 1.1391 \\
\hline$N 17$ & 0.9493 & 0.9666 & 1.0324 \\
\hline N18 & 1.0317 & 1.0543 & 1.0425 \\
\hline Total & 18.2024 & 18.0771 & 20.0603 \\
\hline Mean & 1.0112 & 1.004 & 1.114 \\
\hline
\end{tabular}

Table 5. Comparative results

\begin{tabular}{|c|c|c|c|}
\hline Ref. & Method & Dataset & Performance \\
\hline Dogan vd., (2017) & $\begin{array}{c}\text { Image Processing and } \\
\text { ANN }\end{array}$ & 144 Sample & $\begin{array}{l}\% 97.18 \\
\% 99.87\end{array}$ \\
\hline Dogan vd., (2015) & $\begin{array}{l}\text { Image Processing, ANN } \\
\text { and Statistical Features }\end{array}$ & 60 Sample & $\mathrm{R}^{2}=0.9837-0.9961$ \\
\hline $\begin{array}{l}\text { Kewalramani and } \\
\text { Gupta, (2006) }\end{array}$ & $\begin{array}{c}\text { Ultrasonic Pulse Velocity } \\
\text { and ANN }\end{array}$ & 96 Sample & --- \\
\hline Ni and Wang, (2000) & $\begin{array}{c}\text { Multi-layer feed-forward } \\
\text { neural networks }\end{array}$ & 100 Sample & --- \\
\hline Our Paper & $\begin{array}{l}\text { Image Processing, ANN } \\
\text { and Statistical Features }\end{array}$ & $\begin{array}{c}210 \text { Sample (70 Travertine+70 } \\
\text { Andesite+70 Limestone) }\end{array}$ & $\begin{array}{c}\text { Travertine=\%99.47 } \\
\text { Andesite=\%93.89 } \\
\text { Limestone=\%94.19 }\end{array}$ \\
\hline
\end{tabular}

\section{Conclusions and recommendations}

In this study, no problem was experienced and it was concluded successfully. In this article, both an image processing application and an artificial neural network application that can be integrated with this application have been developed. Basically, the compressive strength properties of stone samples used in masonry structures were calculated with this application, which provides non-contact measurement. It has been observed that the application developed 
as a result of the experimental studies performed can give extremely successful and accurate results.

One of the most important limitations of the proposed method is the isolation of environmental conditions while images are taken of the samples. This situation may affect the success of the method. In addition, it would be better to use new approaches in the literature such as deep learning in order to obtain more stable results in terms of accuracy.

\section{Acknowledgment}

This study was supported by T.C. Ardahan University Scientific Research Projects Coordinator with project number 2017/008.

\section{References}

ASTM, D., (1990). 2845 (1983) Standard test method for laboratory determination of pulse velocities and ultrasonic elastic constants of rock. American Society for Testing and Materials, West Conshohocken.

Dogan, G., Arslan, M. H., \& Ceylan, M. (2017). Concrete compressive strength detection using image processing based new test method. Measurement, 109, 137-148.

Dogan, G., Arslan, M. H., \& Ceylan, M. (2015). Statistical feature extraction based on an ann approach for estimating the compressive strength of concrete. Neural Network World, 25(3), 301.

Duan, G., Chen, Y. W., \& Sakekawa, T., (2008). Automatic optical inspection of micro drill bit in printed circuit board manufacturing based on pattern classification, Instrumentation and Measurement Technology Conference Proceedings (IMTC), pp. 279-283.

Hornby, B. E., (1998). Experimental laboratory determination of the dynamic elastic properties of wet, drained shales. Journal of Geophysical Research: Solid Earth, 103(B12), 29945-29964.

Hsiao, P. Y., Lu, C. L., \& Fu, L. C., (2010). “Multilayered Image Processing for Multiscale Harris Corner Detection in Digital Realization”, IEEE Transactions on Industrial Electronics, vol. 57, no: 5, pp. 1799-1805.

Kewalramani, M. A., \& Gupta, R. (2006). Concrete compressive strength prediction using ultrasonic pulse velocity through artificial neural networks. Automation in Construction, 15(3), 374-379. 
Ni, H. G., \& Wang, J. Z. (2000). Prediction of compressive strength of concrete by neural networks. Cement and Concrete Research, 30(8), 1245-1250.

Ozkaya, S. G., Baygin, M., Ozdemir, M. A., \& Kazaz, I., (2017). Image Processing Based Analysis of the Compressive Strength for the Stones Used In Historical Masonry Structures. International Journal of Computer Science and Software Engineering, 6(10), 216-222.

Öziçer S., \& Uyanık O., (2015). Mevcut yapıların beton dayanımının jeofizik (ultrasonik)yöntemler ile belirlenmesi. Kentleşme ve yapı inceleme çalıştayı.

Qixian, L., \& Bungey, J. H., (1996). Using compression wave ultrasonic transducers to measure the velocity of surface waves and hence determine dynamic modulus of elasticity for concrete. Construction and building materials, 10(4), 237-242.

Y. R. Chen, K. Chao \& M. S. Kim., (2002). "Machine vision technology for agricultural applications”, Computers and Electronics in Agriculture, vol. 36, pp. 173-191.

Yazdi, L., Prabuwono, A. S., \& Golkar, E., (2011). Feature extraction algorithm for fill level and cap inspection in bottling machine, International Conference on Pattern Analysis and Intelligent Robotics (ICPAIR), vol. 1, pp. 47-52. 